\author{
St udia Philosophic a \\ Wrat i s l avi e n s i a \\ vol. XIV, fasc. 1 (2019) \\ DOI: $10.19195 / 1895-8001.14 .1 .8$
}

\author{
KRZYSZTOF BRZECHCZYN \\ ORCID: 0000-0001-8789-5641 \\ Adam Mickiewicz University \\ Institute of National Remembrance, Poznań branch
}

\title{
Communitarian Dimensions in the Socio-Political Thought of the Solidarity Movement in 1980-1981*
}

\begin{abstract}
The purpose of this paper is an interpretation of the social and political thought of the Solidarity movement in the light of the political philosophy of communitarianism. In the first part of the paper, the controversies between liberalism and communitarianism are characterized in order to outline the communitarian response toward the authoritarian/totalitarian challenge. In the second part, the programme of a self-governing republic created by Solidarity is interpreted in the spirit of communitarianism. I reconstruct the ideal vision of human being expressed in official trade union's documents and essays of Solidarity's advisers (e.g., Stefan Kurowski and Józef Tischner), and the efforts of the movement for telling the truth about history and its vision of Polish history. Also, I interpret the programme of Self-Governing Republic adopted during the First National Convention of Delegates of Solidarity. In these programmatic documents of Solidarity, one may find ideas characteristic both of the communitarian and liberal political philosophy. However, the liberal ones - including, primarily, the guarantee of human and citizens' rights, and of individual liberties - were subordinated to the postulate of reconstructing the national and social community. In the course of transformation after 1989, these communitarian elements of Solidarity programme, incompatible with liberal ideological agenda, have been erased.
\end{abstract}

Keywords: Solidarity, communitarianism, liberalism, the programme of Self-Governing Republic, transformation

\footnotetext{
* This article was written within the framework of the Central Research Project of the Institute of National Remembrance, "Opozycja i opór społeczny w Polsce 1956-1989" ("Opposition and social resistance in Poland 1956-1989").
} 


\section{On Certain Problems of the Interpretation of the Social and Political Thought of Solidarity Movement in the Light of the Communitarian Political Philosophy}

Communitarianism arose as an intellectual reaction to John Rawls's Theory of Justice. In the realm of social practice, communitarians objected to the neoliberalist politics of Ronald Reagan's and Margaret Thatcher's time in power. The main representatives of that stream of intellectual thought were Alasdair MacIntyre, Michael Sandel, Michael Walzer, and Charles Taylor, although not all of those thinkers aligned themselves with communitarian political philosophy, especially in respect of the practice of social movements which invoked communitarianism. ${ }^{1}$ That is definitely one of the reasons why it is difficult to interpret the whole of communitarian philosophy which arose in opposition to liberalism or, rather, to what those authors considered to be liberalism. It seems that the starting point in the reconstruction of the dispute between the two strands in political philosophy should be the concept of an individual. Communitarians view liberalism as a philosophy which presupposes an atomistic concept of an individual whose identity is formed primarily on the basis of that individual's personal choices. Individuals understood in that way do not have to play the social roles imposed upon them in the society of their birth - although they can take those roles into account. That is because the concepts of a nation, religion, or sex, defined from the perspectives of history and culture, are accidental in nature and the measure of the authenticity of an individual is the degree to which that individual is liberated from the restrictions imposed by those concepts.

Communitarians, on the other hand, emphasize the social nature of the formation of individual identity because an individual is immersed in a family community, at the very moment of coming into existence, and, while growing up, joins a religious community, various social communities, and, finally, the national community. Those communal identities are the material used by an individual to construct, according to certain supra-individual cultural rules, his or her own, personal, unique identity. In McIntyre's words: "I am the subject of a history that is my own and no one else's, that has its own peculiar meaning." ${ }^{2}$

1 The characteristic of communitarianism presented in this article is based on such works as: P. Przybysz, "Dwa modele człowieka (O sporze liberalizm-komunitaryzm)," Arka 51 (1994), pp. 22-39; A. Szahaj, Jednostka czy wspólnota? Spór liberałów z komunitarystami a sprawa polska, Warszawa 2000; P. Śpiewak, "Poszukiwanie wspólnot," [in:] Komunitarianie. Wybór tekstów, P. Śpiewak (ed.), Warszawa 2004, pp. 5-15; K. Frysztacki, "Komunitaryzm: obietnice, nadzieje, ograniczenia," Diametros 8 (2006), pp. 108-119; M. Kuniński, "Komunitaryzm, czyli o bliskich związkach filozofii politycznej i socjologii," Diametros 8 (2006), pp. 127-131; A. Miętek, "Spór liberałów z komunitarystami," Dialogi Polityczne 7 (2007), pp. 101-111; Ł. Dominiak, Wartość wspólnoty. O filozofii politycznej komunitaryzmu, Toruń 2010; A. Modrzyk, "Ku wspólnocie posttradycyjnej. Axel Honneth jako krytyk komunitariańskiej filozofii politycznej," Praktyka Teoretyczna 1 (2010), pp. 27-40; J. Bartyzel, "Wartość wspólnoty. Filozofia polityczna komunitaryzmu," Myśl Konserwatywna 18 May 2015, http://myslkonserwatywna.pl/prof-bartyzel-wartoscwspolnoty-filozofia-polityczna-komunitaryzmu (accessed: 12.01.2017); A. Chmielewski, "Komunitaryzm," [in:] Panorama wspótczesnej filozofii, J. Hołówka, B. Dziobkowski (eds.), Warszawa 2016, pp. 435-453.

${ }^{2}$ A. MacIntyre, After Virtue: A Study in Moral Theory, Notre Dame 2007, p. 217. 
The immersion of an individual in a social community raises the question about nature, constitutive characteristics, and manner of the organization of a good society. The disagreements between liberalism and communitarianism concerning the issue of an ideal social order can be presented as the following series of oppositions:

- proceduralism versus common good,

- economic reductionism versus autonomism,

- ahistoricism versus traditionalism, and

- cosmopolitanism versus patriotism.

In the proceduralist vision of social order, the state is seen as a formal framework in which disputes between individuals and social groups are settled. According to Paweł Śpiewak "liberals, as they take such a point of view, agree that the state is only based on the law which has the priority over any vision of the good, and its interpreters and administrators, that is, lawyers, obtain the position of priests of that form of government." In the communitarian vision of social order, the common good is a superior social value determined by way of a social dialogue.

The differentiation between reductionism and autonomism draws on Walzer's concept of spheres of justice present in the basic spheres of social life, namely, in politics, economy, and culture. In Adam Chmielewski's interpretation: "Each of those spheres remains relatively autonomous because there is no universal medium of the exchange of things considered as goods in particular spheres. Even money, which makes it possible to exchange goods in the economic sphere, cannot be the means for purchasing or exchanging goods in other spheres: you cannot buy talent, a political position, a scientific title, wisdom, and many other things for money."

Liberalism is seen as a philosophy which assumes that the accidental significance of the community in which an individual was born and lives, so the knowledge about the past of that community and of its cultural tradition only has relative importance - it is rather a burden than an advantage in the construction of an individual's identity. In the communitarian approach, in order to lead a morally good life, an individual should possess the knowledge about the set of practices and principles binding in a given society. The knowledge about the past of a community is a constitutive element of the knowledge about that community. According to McIntyre: "I am someone's son or daughter, someone else's cousin or uncle; I am a citizen of this or that city, a member of this or that guild or profession; I belong to this clan, that tribe, this nation. Hence what is good for me has to be the good for one who inhabits these roles. As such, I inherit from the past of my family, my city, my tribe, my nation, a variety of debts, inheritances, rightful expectations and obligations. These constitute the given of my life, my moral starting point. This is in part what gives my life its own moral particularity."

The fate of an individual only becomes comprehensible and meaningful again when it is woven into the history of greater wholes - nations. An individual's at-

\footnotetext{
${ }^{3}$ P. Śpiewak, "Poszukiwanie wspólnot," p. 6.

${ }^{4}$ A. Chmielewski, "Komunitaryzm," p. 449.

${ }^{5}$ A. MacIntyre, After Virtue, p. 220.
} 
titude toward its closest national society is shaped by the virtue of patriotism ${ }^{6}$ which is juxtaposed with liberal cosmopolitanism. That virtue explains, first of all, the emotional and moral tie between an individual and a nation, which makes the accidental fact of being born in a certain place a special event for an individual. The national culture in which an individual is immersed is a depositary of moral values as well as of the rules for practising those values, which make up the basic set of social practices. What is more, the individual narration becomes comprehensible and regains meaning when it is woven into greater wholes of a national community. However, as noted by MacIntyre, it may happen that a nation renounces its own history or distorts and mystifies it.

The problem of using a communitarian conceptual framework in the interpretation of the social and political thought of Solidarity lies in the difference between the historical and social contexts of those two intellectual phenomena. Communitarianism arose and developed in opposition to liberalism, while the social thought of Solidarity arose in opposition to real socialism. The interpretation of the social and political thought of Solidarity in communitarian categories would only be possible if we managed to reconstruct the communitarian critique of real socialism or, more broadly, totalitarian systems, or develop the political philosophy of communitarianism to such a degree that it would be applicable to the analysis of those kinds of societies.

Two varieties of the critique of non-liberal forms of government are discernible in the communitarian philosophy. One of them is the concept of a responsive society, represented by Amitai Etzioni, which posits a balance between individual autonomy and social order. A society is a result of the activity of two opposing powers: "The traditional contradiction between order and autonomy can be minimized by responsiveness that considers the community's historical position. When centripetal forces pull too much toward order, an emphasis must be placed on autonomy. When centrifugal forces pull too much toward autonomy, order must be given greater weight."7 In Etzioni's approach, totalitarian systems (real socialism) are instances of societies in which individual liberty is dominated by a radical trend toward keeping social order. In such conditions, the communitarian political strategy should consist in increasing the scope of individual liberties and a communitarian should become a liberal.

In Daniel A. Bell's approach, an individual's autonomy and political order are not necessarily contradictory. What is more, a political order becomes stable when it guarantees civil liberties to its members. It is the lack of civil liberties that breaks the spirit of a community and lowers citizens' engagement in public matters, which results in the destabilization of public order. From that point of view, a totalitarian (or authoritarian) system does not only limit the scope of individual freedom but also destroys and subverts social ties and the sense of a community

${ }^{6}$ P. Śpiewak, "Poszukiwanie wspólnot," p. 12.

7 A. Etzioni, "The Responsive Community: A Communitarian Perspective," American Sociological Review 61 (1995), p. 1. Philip Selznick argues in a similar way. See: P. Selznick, "Thinking about Community: Ten Theses," Society 32 (1995), pp. 33-37. 
in a society. ${ }^{8}$ Thus, according to Bell, in totalitarian conditions "communitarians ought to remain communitarians even in China, that is, they ought to be stressing the need for more community as a goal, combining this moral stance with the argument that as empirical matter greater protection of individual liberties is the best (and easiest to implement) starting point for getting there." 9

We can interpret Bell's position as follows: communitarian critique should present a different set of arguments with respect to the liberal order than with respect to the totalitarian order. Those two ideological and social systems subvert the foundations of a good society in different ways. In such a case, then, the liberalism versus communitarianism opposition ought to be replaced with the triad of liberalism, communitarianism, and totalitarianism, whereby both liberalism and totalitarianism are criticized, albeit in different ways, from the point of view of communitarian philosophy.

In this article, I can only sketch the direction of such a reconstruction (or development) of the communitarian critique. It is not proceduralism but political arbitrariness that threatens common good in real socialism. Power in a totalitarian system is driven by its own political interest. It is not bound by public opinion, legal rules, or interests of other social classes which, in a totalitarian order, cannot be freely articulated. Since all spheres of life are subjected to the interests of the political power, the principle of the autonomy of various spheres of social life is violated not by economic reductionism but by the political one.

Instead of free development of historical consciousness (including scientific research on the past, the popularization of a vision of the past for educational and integrative purposes, and the cultivation of individual historical memory) there is mythologization of it, consisting in the omission of selected, uncomfortable information and in the foregrounding of other data which is favourable to the authorities. That happens in a dogmatic way. The power which has a monopoly of the means of information popularizes a desirable image of the past, while undesirable researchers are censored, marginalized, and - depending on the period of time - repressed. The image of the past fulfills ideological functions - it legitimizes the rule and interests of the authorities.

In the case of Poland, the subjugation of the Polish People's Republic to the Soviet Union eliminated patriotism which was combated as nationalism and it was replaced with internationalism understood as loyalty to the Soviet Union and the idea of communism.

Moreover, Polish Solidarity arose before the appearance of publications initiating communitarian social reflection and its thought was more eclectic. ${ }^{10}$ The main

${ }^{8}$ D.A. Bell, "A Communitarian Critique of Authoritarianism," Society 32 (1995), pp. 38-43; D.A. Bell, "A Communitarian Critique of Authoritarianism: The Case of Singapore," Political Theory 25 (1997), pp. 6-32.

${ }^{9}$ D.A. Bell, "A Communitarian Critique of Authoritarianism: The Case of Singapore," p. 41.

10 See: K. Brzechczyn, "The Forgotten Legacy of Solidarność and Lost Opportunities to Build a Democratic Capitalist System Following the Fall of Communism in Poland," [in:] Twenty Years after the Collapse of Communism: Expectations, Achievements and Disillusions of 1989, N. Hayoz, L. Jesień, D. Koleva (eds.), Bern 2011, pp. 400-401. 
works of communitarian political philosophy were published in the 1980s and their authors were able to present their reflections in a more systematic manner. Those works are: Alasdair MacIntyre's, After Virtue: A Study in Moral Theory (1981), Michael Sandel's Liberalism and the Limits and Justice (1982), Michael Walzer's Spheres of Justice: A Defense of Pluralism and Equality (1983), and Charles Taylor's Sources of the Self: The Making of Modern Identity (1989).

\section{The Vision of a Human Being in the Social and Political Thought of Solidarity}

The ideal of an individual held by Solidarity can be found in the programme documents of that Union and in essays written in 1980-1981. One of those documents was "Kierunki działania Związku w obecnej sytuacji kraju. Tezy do dyskusji" (The Directions of the Activity of the Union in the Current Situation in the Country. Theses for a Discussion $)^{11}$ prepared by a team of experts of The Centre for Social and Professional Work of the Independent Self-governing Trade Union Solidarity and Stefan Kurowski's "Wstęp do programu i założeń ideowych" (An Introduction to the Programme and Doctrinal Assumptions) published also in the Tygodnik Solidarność weekly. ${ }^{12}$ Those works are complemented by Józef Tischner's precious Etyka Solidarności (The Ethics of Solidarity) written in the form of short essays in 1980-1981. Tischner's sermon "Polska praca jest chora" (Polish Labor is Ill), given during the mass which opened the second part of the First National Convention of Delegates, became an official Trade Union's document.

The basic values named in the "Directions" were "ideals of patriotism, social justice, and citizens' democracy,"13 while the sources of inspiration for action were: "the best national traditions, the ethical principles of Christianity, the political calls of democracy, and the socialist social thought." "4

The four sources of inspiration mentioned above are elaborated upon further in that document. Also emphasized is the attachment to the Polish culture which is an inalienable part of the European culture. Although the author notes that one principal aspect of the Polish culture is its relationship with Catholicism, he also stresses the fact that it combines various religious and secular traditions, thanks to the principle of tolerance. Patriotism provides an "irreplaceable platform for integration and social generosity with respect to the homeland"15 and national values provide the foundation for the formation of the Polish society.

Another group of values is derived from acting in a community. It comprises "solidarity, collegiality, the ability to sacrifice" (for the Union and the "general so-

11 "Kierunki działania Związku w obecnej sytuacji kraju. Tezy do dyskusji," Tygodnik Solidarność 3 (1981), pp. 1-8 (insert).

12 It was published in two parts as: S. Kurowski, "Inspiracje i źródła programu," Tygodnik Solidarność 4 (1981), p. 5; and S. Kurowski, "Wartości ideowe," Tygodnik Solidarność 5 (1981), p. 9

13 Ibid., p. 1.

${ }^{14}$ Ibid.; emphasis in the original.

15 Ibid., p. 2. 
cial interest"16), and the "idea of the brotherhood of working people." The principle of social justice should be respected in union activity and be the principle on which the functioning of the state rests. Social justice is based on the "inherent dignity of a human person, of a working person and of that person's effort." "The principles of social justice and of the dignity of a human person mean that "in their deepest essence, people are equal." 18 That conviction finds its expression in the "realization of social egalitarianism"19 and all-embracing democracy in public life. That gave rise to two derivative principles: the principle of offering remuneration depending on the quality, quantity, inconvenience, and harmfulness of work and "the principle of satisfying the minimal social needs," which meant the satisfaction of the basic needs with regard to food, accommodation, clothing, as well as social and cultural needs. The latter principle was assigned priority over the former one. The principles of social justice should be complemented with reliability in professional work, high work ethics, trustworthiness, and the principle of good labour.

The realization of the principle of democracy in public life was understood as honouring the civil liberties guaranteed by the constitution of the Polish People's Republic, such as: the right to voice one's opinions, freedom of speech and of print, the right to reliable information, the right of assembly, and the right to freedom of association with others.

In the "Directions" it was declared that: "Our Union is an organization of people of a variety of worldviews, open to people of all denominations, as well as to nonbelievers, however, a great majority of the members, just like a majority of our nation, was raised as Catholics. Christian inspiration was one of the basic worldview values we have included in the programme. The cross next to the eagle hung at many Union premises, reminds our members of their moral heritage and fills them with faith in the righteousness of our cause. We will continue drawing on that stream of inspiration while maintaining the secular character of our organization." 20

Stefan Kurowski's proposal also included an extended set of the characteristics of an ideal human being. ${ }^{21}$ The catalogue of interrelated worldview values was divided into two groups. The first group includes "a set of general moral ideas which were violated and slighted in the system in an especially cynical and open way, against which practice we have protested." ${ }^{22}$ Kurowski's priority was honesty understood as a balance between the work done and the benefits received by a person. The principle of honesty led to respect for such values as reliability, truthfulness in public life, the principle of good faith when conducting negotiations, and fighting pathologies in social life (alcoholism).

\footnotetext{
${ }^{16}$ Ibid., p. 1.

17 Ibid.

18 Ibid.

19 Ibid.

${ }^{20}$ Ibid., p. 2.

${ }^{21}$ S. Kurowski, "Wartości ideowe," Tygodnik Solidarność 5 (1981), p. 9; the article was also published in Tygodnik Powszechny 16 (1981), and, repeatedly, as a separate brochure.

${ }^{22}$ Ibid., p. 9.
} 
As regards the second group of values, Kurowski saw them as "values arising from communal activity," ${ }^{23}$ such as: solidarity, collegiality, ability to sacrifice oneself for the union community and for broader social interest. One such value is the "idea of the brotherhood of working people united against abuse, no matter what the slogans are which mask that abuse." 24

Another group of values is a set of ideals "making up an image of the society we want to co-create." 25 The primary value of that kind is the "inherent dignity of a human person, the dignity of a working person and of that person's effort" 26 which should be the "foundation for the construction of relationships in a new society."27 That basic principle gives rise to the principle of working people's authentic participation in the social and public life of a country and a state, that is, to self-government in public life (local self-government) and in professional life (workers' self-management). That participation can only be fully realized in a democracy which is a constant value of the Union. That means striving for "increasing competences of the existing representative bodies: the Sejm and national councils and, more importantly, we will strive to make those institutions fully representative of the society, truly elected and not just appointed by means of fake voting." ${ }^{28}$ Moreover, the principle of authentic participation in social life meant a refusal to participate in superficial institutions.

The basic task of the Union, that is, the defence of working people, is realized by respecting the principle of social justice which gives rise to certain secondary values, such as the right to work, fair and just payment, the rule of law, and civil liberties. The innate dignity of a human person and the principle of justice lead to the idea of equality understood as a "condition for equal opportunities, an objection to all privileges, also those which can accompany power, and not allowing such a differentiation of citizens' income and social position as could violate our social ideals in a fundamental way." 29 Kurowski made the reservation that "the principle of equality understood in a mechanical way always leads to tyranny and a contradiction of itself." 30

The starting point for Tischner's reflections is the dialogic nature of reality. Solidarity was for Tischner, first of all, an opportunity for rebuilding human dignity. Its basis was the renewal of conscience. In Tischner's interpretation, the anthropology of Solidarity included the presumption that a "human is a being endowed with conscience" which is a natural ethical sense prior to and independent from various ethical systems and theories. Humans have the duty to exercise their conscience. If that duty is neglected, the voice of conscience is muted and renounced. Conscience can be exercised in the quest for truth, which creates the possibility of a dialogue.

\footnotetext{
23 Ibid.

${ }^{24}$ Ibid.

${ }^{25}$ Ibid.

26 Ibid.

27 Ibid.

28 Ibid.

29 Ibid.

30 Ibid.
} 
A dialogue must fulfil certain conditions accepted by both parties: "neither of us can learn the truth about ourselves if we remain distanced, closed within the walls of our fears; we must take a look at ourselves from the outside, so to speak, I must take a look at myself with your eyes and you - at yourself with my eyes; we have to compare those views in a conversation and only then will we be able to answer the question about the truth about us." 31 A conversation is not an exchange of blows but a way to find common beliefs. For that goal to be reached the parties must admit that each of them is right to some extent.

Such a possibility is offered by the Solidarity movement which is "neither a concept nor a ready-made ethical theory, it is an idea." 32 In Tischner's view, "while concepts can usually be easily defined, ideas remain somewhat undetermined. They are models of things more than an expression of their actual state. Solidarity is, for us, something to emulate, which is being defined while it is being realized and which must continually be defined anew."33

In his works, Tischner paid special attention to analysing professional work which is a particular form of a dialogue during which people do not exchange words but the results of their work. Those results combine the past with the future $^{34}$ : "The scope of a work conversation is large. Let us consider: the land was prepared by our forefathers, the scythe-by workers, bread was baked by a baker and a poet satisfied his hunger with it. When I work, I join a discourse which had begun before I was born. I am also a link between the past and the future. I am an heir to work. I am also a link in the present between those who excavated the ore and those who will buy the bread." 35

According to Tischner, the measure of work is human life which should be served by work. When that is not the case, human work is ill. It is too burdensome, not because a worker fights with the used material but because people do not coordinate their cooperation well so the dialogic nature of human work is disturbed and its meaning is subverted, which causes unnecessary suffering. Tischner called those states moral exploitation of work which is "related to a situation of some lie in which working people find themselves." 36

In his sermons, Tischner also analysed other spheres of human activity: scientific, artistic, political, and public, which he combined by means of the category of rootedness - the basis for the creation of a community. The concept of rootedness connected various spheres of human activity, located them in a historical time, and endowed them with supra-individual meaning. Tischner asked the following question. "When we choose a homeland, we also choose our history. The choice of our history means that we put certain events in the background and focus on some other events as our models. That is extremely important. By drawing on history,

\footnotetext{
31 J. Tischner, Etyka Solidarności, Paris 1982 [1981], p. 15.

32 Ibid. p. 11.

33 Ibid., p. 11.

${ }^{34}$ Ibid., p. 18.

${ }^{35}$ Ibid., p. 19.

${ }^{36}$ Ibid., p. 23.
} 
a person partakes of the dignity of those people whose work he or she continues. Whose work does the Polish conscience want to continue today?"37

\section{The Fight of Solidarity for Telling the Truth about History}

The fight for the shape of historical consciousness was one of the fields of the conflict between society and the authorities. Solidarity tried, in countless publications, to present the true Polish history. Those publications were devoted to two issues: the relationship between Poland and Russia - and, later, the Soviet Union - and the history of the Polish People's Republic. Countless publications were devoted to the genesis of the regaining of independence, the Polish-Soviet War in 1920, the Ribbentrop-Molotow pact, the Soviet invasion of Poland on September 17, 1939, the occupation of the Eastern part of the Polish Republic, the Katyn massacre, and the Warsaw Uprising. ${ }^{38}$

In November 1980, the National Coordinating Commission issued a special "Appeal for the Anniversary of the November Uprising" calling for a peaceful and dignified commemoration of the anniversary of that independence movement. Fearing the possible anti-Soviet provocation, the appeal contained the following suggestion for commemorating the anniversary: "concerts, meetings, lecturesthey should take place in closed rooms and not on streets or squares. We must remember that any unrest or rash manifestations can actually contribute to unnecessary and potentially harmful exacerbation of the situation in the country." 39

Officially, Solidarity considered itself to be the succeeding link in the chain of social protests against the authorities of the Polish People's Republic. The programme of Solidarity was preceded by a solemn restatement of the 21 Gdańsk postulates and in its first chapter it was underlined that the Independent Self-governing Trade Union "Solidarity" was born in the summer of 1980 as a result of strikes which constituted a link in a series of social protests in the Polish People's Republic. Also mentioned in that context were the Poznań 1956 protests, the students' protest action in March 1968, December 1970 protests, and strikes and repressions against Radom and Ursus workers in June 1976. The Union grew out of the economic protest against the scarcity of material goods, fight for dignity, the moral protest against the hypocritical public life, and the social protest against the lack of freedom of speech and of civil liberties. The authors of the programme announced that the Union "joins many social movements and connects people

${ }^{37}$ Ibid., p. 78 .

${ }^{38}$ Historical consciousness of the Solidarity movement has been described in greater detail in: M. Kula, Narodowe i rewolucyjne, Warszawa 1991, p. 277-282; M. Meller, "Rola myślenia o historii w ruchu "Solidarność" w latach 1980-1981," [in:] Solidarność w ruchu, 1980-1981, M. Kula (ed.), Warszawa 2000, pp. 219-266.

39 "Apel KKP w rocznicę powstania listopadowego," 26 November 1980, [in:] Dokumenty Krajowej Komisji Porozumiewawczej i Komisji Krajowej NSZZ "Solidarność" (1980-1981), M. Owsiński (ed.), Warszawa 2012, p. 104. 
with different worldviews, political views, and religious beliefs, and of different nationalities." $\$ 0$

However, during the less formal discussions about the strategy of the Union, Solidarity was understood as a link in a chain of uprisings and independence wars. ${ }^{41}$ One example could be the discussion during the so-called Bydgoszcz crisis, during a meeting of the National Coordinating Commission, on 23 March 1981. Some participants of a discussion about a general strike, attended by activists and advisors of Solidarity: Bronisław Geremek, Tadeusz Mazowiecki, Karol Modzelewski, Jan Olszewski, Władysław Siła-Nowicki, and Andrzej Słowik, compared the political situation to such events as the Targowica Confederation, deportations to Siberia, the defence of Westerplatte, ${ }^{42}$ and, most often, to the Warsaw Uprising. One characteristic text was Jan Olszewski's speech, reprinted in many publications of the Solidarity movement, in which the author invoked the threat on the part of the Soviet Union and appealed to national solidarity, speaking to the National Commission: "I would like us to become aware [...] that although the authorities are on the other side, at this moment they are, as regards their core, assumptions, and functions, the only Polish power possible here and that we do not want to replace that power with a foreign one, whatever the differences between us and the authorities." ${ }^{3}$ As regards the discussion about the strategy of the Union, Olszewski remembered the moment when the decision about starting the Warsaw Uprising was made: "I was a scout in the Gray Ranks [Szare Szeregi] who did not understand that at all, for whom it was just a play but I know that as regards those older, a bit older colleagues of mine, they believed their commanders so much that they would have fulfilled any order and would not have done a thing without an order. It was claimed that the uprising had to be started because they were demanding it and otherwise they would have just gone to fight spontaneously. That was not true. I know that today, in this room, there would be many of those who are not and I know why they are not here." ${ }^{4}$

The programme documents emphasized the historical importance of the creation of Solidarity, employing the dichotomic division of the Polish nation represented by the Union and the authorities which served the Soviet interests. In the "List do Polonii całego świata" (Letter to the Polish people around the world) the authors wrote: "Our homeland is going through a very important period. The fate of our nation is being decided. Here, along the Vistula River, a new Poland is being born, on the foundation of social and national brotherhood. 'Solidarity', born out of the will of the whole nation, is not only a trade union of working

40 "Program NSZZ 'Solidarność' uchwalony przez I Krajowy Zjazd Delegatów," Tygodnik Solidarność 29 (1981), p. 1.

${ }^{41}$ See: K. Brzechczyn, "Od rewolucji proletariackiej do powstania narodowego. Przegląd konceptualizacji 'Solidarności' w naukach społecznych i humanistycznych," Pamięć i Sprawiedliwość 2 (2013) pp. 263-289.

${ }^{42}$ Komisja Krajowa NSZZ 'Solidarność,' Posiedzenie w dniach 23-24 marca 1981, Warszawa 1986, pp. 73-94.

43 Ibid., p. 85.

${ }^{44}$ Ibid., p. 87. 
people but also a citizens' social movement of people aware of their rights as well as of their duties to the homeland and to its independence." 45

\section{The Programme of the Self-governing Republic: Between Communitarianism and Liberalism}

The vision of social order promulgated by Solidarity matured in the programme of the Union adopted during the First National Convention of Delegates. The programme contained ideological layers from both liberal and communitarian political philosophy. The programme, however, defined the catalogue of basic values of Solidarity in a slightly different manner than the Kierunki. There is no mention in the programme about the "socialist social thought" and "socialism"; instead, as the source of ideological inspiration, there appears John Paul II's thought: "Solidarity', as it defines its aspirations, draws on the values of Christian ethics, our national ethics, and the workers' and democratic tradition of the world of labour. John Paul II's encyclical about human work is a new stimulus for our activity." 46 In a special declaration adopted by the Convention its participants expressed gratitude to the pope for the encyclical Laborem exercens which, as they stated, described the "basic values of working people: solidarity as a factor of power and social order; work which unites people, the duty of fighting for human dignity and for justice, and the development of trade unions." ${ }^{\prime 7}$ Moreover, popular sovereignty was considered to be the basic principle of social life. It was supposed to be supplemented with the idea of freedom and "unrestricted" independence.

One of the basic issues related to the Solidarity revolution of 1980-1981 was the need to define the scope of the postulated social changes in such a way that they did not infringe upon the interests of the Soviet Union in Poland and did not force that country to intervene - hence the term "self-limiting revolution." We could say, then, that the political thought of Solidarity accepted the degree of Soviet influence in Poland and that the consciousness of its existence prevented the Union from reaching for the ultimate strike power - that is, the proclamation of a general strike for an indefinite period of time - in conflicts with the authorities supported by the Soviet Union. For example, in the "Uchwała w sprawie walki psychologicznej z narodem" (Resolution on the psychological fight with the nation) it was declared unequivocally that the "Union does not strive for a bloody confrontation. Our only weapon is the force of conviction used in defence of our rights and the will to refuse working should our interests be endangered. We do not have at our disposal and we do not intend to have tanks, clubs, and other means of coercion." ${ }^{48}$

It was in the stiff framework of those geographic and political conditions that the programmatic vision was being formed. It contained a dualistic division into

45 "List do Polonii całego świata," [in:] I Krajowy Zjazd Delegatów NSZZ "Solidarnośc", Gdańsk 1981, p. 44.

${ }^{46}$ Ibid., pp. 1-2.

47 "Deklaracja," Tygodnik Solidarność 28 (1981), p. 4.

48 "Uchwała w sprawie walki psychologicznej z narodem," Tygodnik Solidarność 28 (1981), p. 6. 
the "authorities" and the "society," and it acknowledged the reality of post-war European geopolitics. One element of that geopolitics was the "principal political shape of the Polish People's Republic" which boiled down to "not questioning the position of the Polish United Workers' Party in the political administration of the state." It was expected that the authorities would not resort to physical violence and would admit the "already obtained citizens' liberties as inviolable and renounce any attempts at restricting them," in return. This would be guaranteed by the authorities treating the Union as a party to the August agreements which were intended to constitute the basis for democratic social changes.

The presented vision of a reconstruction of the political and social life was justified by means of an emphasis on the fact that the appearance of the mass social movement of Solidarity had changed the situation in the country and the conditions of wielding power in Poland. At that time, in order to effectively rule Poland, it was necessary to take into account the will of the society and to act "under its control, according to the principles included in social agreements." Meanwhile, the authorities did no such thing - they did not undertake any reform of the state or any economic reform. As a result, the "manner of governing the country, based on the omni-power of the central party and state institutions, has ruined the country. The prevention of changes, which has been going on for a year now even though it has become impossible to maintain the old style of ruling, has accelerated that process and is driving us fast toward a catastrophe." ${ }^{49}$ In such a situation, it was argued, Solidarity had to withdraw from the reclaiming position and take part in the reconstruction of the economy and the form of government, taking into account, as was enigmatically stated, the "power system which has been formed in Europe after World War II." 50 The vision of the political, economic, cultural, and social reconstruction is a programme of a "road to a self-governing Republic."

Communitarian ideas can be found in the proposals of a reform of the economy, as the authors of the programme opposed the command-and-distribution manner of management as leading to social passivity, precluding rational management, and being the most important structural cause of the social and economic crisis. The economic reform was to be based on a combination of planning, market, and workers' self-management. The basic unit of the new economic system was to be a "social enterprise managed by the personnel represented by a workers' council and headed by an operative director appointed to the position by way of a competition, by the council, and also dismissed by the council." ${ }^{.51}$

On the other hand, the authors of the programme realized that the rationalization of management can lead to the appearance of economic inequalities or deepening of the existing ones. The programme upheld the reclaiming and egalitarian position as it acknowledged the general right to work and to the unemployment benefit, as well as to various forms of state assistance in the case of unemployment. The programme of Solidarity proposed a reform of the remuneration system,

\footnotetext{
49 "Program NSZZ 'Solidarność'...", p. 2

50 Ibid.

51 Ibid., p. 3.
} 
including the unification of benefits supplementing the salaries, the creation of a minimum wage (at the level of a half of the average wage), the abolition of piecework, and the taxation of "excessively high" wages.

The organization of social and cultural life was to be based on the principle of the self-government of various artistic and scientific communities. Also noted was the relationship between leisure and the time devoted to participation in cultural events. The 18th thesis of the programme imposed on the Union the duty of "ensuring that each worker has the necessary amount of leisure and can use it to participate in culture." ${ }^{.52}$ For that reason five-day workweeks were advocated and the authorities of the Trade Union should "ensure that the employment - necessary for social reasons - of employees of social services, trade, services, and cultural, entertainment, sports, and similar entities on Saturdays and Sundays was recompensed by leisure during the week, month, or year." 53

It was believed that economic and social reforms should be aimed at not only an improvement of the material conditions of the society but also at cultural and educational development. Solidarity declared its readiness to fight hypocrisy in all realms of social life. Society was to regain control over public media. Legislative works were planned in the fields of national education, higher education, the press, and publishing houses. The programme opposed central control of education and the concept of ten years of primary school. The creation of a Social Fund of National Culture was planned, drawing on the traditions of the Mianowski Bank, and also a Social Committee of National Education and a Social Council of Culture were proposed. The task of those institutions was to "define cultural and educational politics, as well as allocate the funds dedicated to those purposes." Convention supplemented those proposals with a resolution on higher education which supported the autonomy and self-government of the academic community. ${ }^{55}$ The convent resolution about upbringing asserted that "one of the important tasks of our Union is to take care that the young generations are brought up in the spirit of the truth about the national tradition." ${ }^{56}$ The resolution heralded the publication of special educational brochures helpful in the teaching of history, Polish, and social science in schools and self-study groups. The authors of the "Programmatic Declaration Concerning National Culture" demanded that the role and place of the Catholic Church in the history of Poland and of the whole world, which has brought Poles into "our greater homeland-Europe, be taken into consideration." The declaration also proposed the principle of neutrality of the state with respect to worldviews, the freedom of intellectual and artistic creation, and tolerance. Those motifs were developed in the "Resolution on National Minorities"; its authors declared that Polish citizens belonging to other nations and ethnic groups "[...]

\footnotetext{
52 Ibid., p. 6.

53 Ibid.

${ }^{54}$ Ibid., p. 8.

55 "Uchwała nr 18/81," [in:] I Krajowy Zjazd, p. 44.

56 "Uchwała nr 24/81," [in:] I Krajowy Zjazd, p. 45.

57 "Deklaracja programowa w sprawie kultury narodowej," Tygodnik Solidarność 30 (1981), p. 9
} 
have found in their homeland, shared with Poles, conditions for free development of their culture." 58

Fighting mendacity in the social life resulting from the state monopoly on information also played an important role in the social-cultural part of the programme. The creation of a "management-executive body" was proposed; its members would be appointed by the government, political parties, trade unions, religious organizations, social organizations, artistic associations, and a self-government of the radio and television workers. That body was to supervise and have the decisive voice concerning the aims of radio and television broadcasts. Additionally, the Union leadership planned the creation of their own mass media.

Self-governance was to be the basic form of government in Poland. The term "self-governing Republic" is introduced in chapter 6 of the programme. It also appears in other chapters of the programme. According to thesis 19, "worldview, social, political, and cultural pluralism should form the basis for democracy in the self-governing Republic." The authors also declared support for all forms of association and their readiness to cooperate with organizations with similar programmes. At the same time, the authors opposed the idea of "the statutory authorities of our Union [creating] political organizations." 59 The programme postulated a workers' self-management as the basic principle of the self-governing Republic. Moreover, cooperatives were to regain their autonomous character. The local self-government was to be re-built by means of free elections. Local government were supposed to have far-reaching competences: as a public agent, it would be able to impose local taxes and decide about all local matters not reserved for the competences of the national government bodies. ${ }^{60}$

The programme of Solidarity included a whole package of institutional and legal solutions intended to guarantee basic individual liberties. That may be viewed as a manifestation of the liberal dimension of the Solidarity thought. The Union was going to restore the highest authority of the Sejm in the state and heralded a change of the voting system which was to enable free submission of candidates for members of the Sejm. The most important novum in the programme of Solidarity was the proposal of the creation of a self-governing chamber (or a social-economic chamber) of the Sejm, the task of which would be to "supervise the realization of the programme of an economic reform and of economic politics."

The vision presented in the programme included a political system which would guarantee the most important civil liberties. It demanded that the Polish state should ratify the International Covenant on Civil and Political Rights, and an independent Constitutional Tribunal should be established which would decide about whether laws are constitutional. Also an amendment of the law on associations was postulated. One key element of the new form of government was a reform of the functioning of the judiciary system, including, among other things, the introduction of a self-governing judges' council. That body would have a say

\footnotetext{
58 "Uchwała w sprawie mniejszości narodowych," Tygodnik Solidarność 30 (1981), p. 9.

59 "Program NSZZ 'Solidarność'...", p. 7.

60 "Uchwała nr 25/81," [in:] I Krajowy Zjazd, p. 46.
} 
in nominations to the position of a judge and would guarantee his/her irremovability. The removal of a judge would only be possible in the course of disciplinary proceedings or because of an illness which would preclude to fulfil vocational duties. Jurors and members of magistrate courts judging in criminal cases were to be appointed through direct elections, while the prosecutorial branch was to be subjected to the Ministry of Justice. Moreover, a self-government of attorneys was postulated to guarantee the independence of advocates.

\section{Summary}

In the programme of a self-governing republic created by Solidarity one can find ideas characteristic both of the communitarian and liberal political philosophy. However, the liberal ones - including, primarily, the guarantee of human and citizens' rights, and of individual liberties - were subordinated to the postulate of reconstructing the national and social community. Many liberal critics of Solidarity failed to notice how the individual liberties were situated in the ideological project of the movement and accused Solidarity of populism. ${ }^{61}$

After 1989, whenever the ideological heritage of Solidarity was invoked, it was in the context of, first of all, the liberal motifs and ideas, while the communitarian dimension of the social and political thought of the movement, especially as regards economy, were usually omitted. A detailed analysis of that issue would be beyond the boundaries of this essay. In short, it was a result of the power and interests of the main agents and social classes of the transformation.

\section{a) The power of Solidarity}

In the years 1980-1981, the mass revolutionary movement presented a programme of the ideal of a self-governing republic. In 1981-1989 it transformed into a social movement with a smaller number of supporters which included the youth, the intelligentsia, and the leaders of the workers from the greatest factories. Such a movement was not able nor intended to force the authorities to implement the programme because the social pressure was smaller than in 1980-1981. Moreover, the processes of the emerging of the Union elite, the division into National Executive Committee (Krajowa Komisja Wykonawcza) headed by Lech Wałęsa and Workgroup of the National Commission (Grupa Robocza Komisji Krajowej) led by Andrzej Gwiazda, Marian Jurczyk, Jan Rulewski and Andrzej Słowik limited the democracy inside the Solidarity movement. ${ }^{62}$ The programme of a self-governing republic based on the principle of self-government in various spheres of life was becoming increasingly dysfunctional from the point of view of the interests of the Union leadership.

61 A. Walicki, "Paradoksy Polski Jaruzelskiego," [in:] A. Walicki, Polskie zmagania z wolnościa, Kraków 2000, pp. 11-34.

${ }^{6}$ J. Skórzyński, Ugoda i rewolucja. Władza i opozycja 1985-1989, Warszawa 1995, p. 181; see also: K. Brzechczyn, "The Round Table Agreement in Poland as a Case of Class Compromise: An Attempt at a Model," Debatte: Journal of Contemporary Central and Eastern Europe 18 (2010), pp. 195-202. 
b) The interests of the party apparatus

The power relationships between the state authorities and Solidarity were such that the party apparatus was ready to give up the political rule in return for the possibility of its own transformation into a class of owners. ${ }^{63}$ The idea of workers' self-management turned out to be incompatible with the mechanisms of the "enfranchisement of nomenklatura" (former apparatchiks - members of the apparatus of the Polish United Workers' Party) defined as "the transfer of current political privileges resulting from the position in the administrative hierarchy of the power apparatus into economic capital." ${ }^{64}$

c) The global intellectual domination of neoliberalism

The economic reform proposed in 1988-1981 were outlined in a different ideological atmosphere, gradually dominated, in the Western world, by the influence of neoliberalism propagated by Ronald Reagan and Margaret Thatcher. The influence was reflected in Poland by an increase in the number of books and magazines propagating the liberal economic concepts. The palpable change of the intellectual atmosphere caused the idea of an economy based on workers' self- management to appear more and more anachronistic.

d) The utopian nature of the self-governing republic

Finally, one should add that workers' self-management on the scale postulated by the programme of a self-governing republic has never been introduced in practice anywhere in the world. For that reason, liberalism, both as a worldview and an ideology, appeared more attractive and capable of justifying, in a natural way, the free market based on private property.

Liberalism, at least the one propagated in Poland by newspapers at the beginning of the 1990s advocated the primacy of private property over social property, regardless of the owners' social origins and the legality or ethicality of the ways in which they have gained wealth. Due to the Zeitgeist of the end of the 1980s and the beginning of the 1990s the ideas of solidarity and self-government lost their supporters to the liberal doctrine which offered a flawless justification of the acquisition of material goods by both nouveau riches whose only resources were their ingenuity and hard work, and economic oligarchs who relied on their political connections. The idea of the self-governing republic, based on communal values, was not able to attract such a following. It is difficult to say how the idea of the common good would be compatible with personal enrichment because no one seriously tried to discuss its assumptions, primarily for the reason that its programme was inconsistent with the interests of the main agents of the transformation, i.e., the party nomenklatura, the elites of Solidarity who took over the political power,

${ }^{63}$ More on this, see: K. Brzechczyn, "The Collapse of Real Socialism in Eastern Europe versus the Overthrow of the Spanish Colonial Empire in Latin America: An Attempt at Comparative Analysis," Journal of Interdisciplinary Studies in History and Archaeology 1 (2004), pp. 105-133.

${ }^{64}$ P. Strzałkowski, "Polityczne i społeczne uwarunkowania przedsiębiorczości ekonomicznej," [in:] Zmierzch socjalizmu państwowego, W. Morawski (ed.), Warszawa 1994, p. 349. 
and the freshly created propertied class who relied on their connections with the state apparatus. Their interests were the greatest obstacle to the construction of democratic capitalism compatible with principles of social solidarity.

Translated by Agnieszka Wróblewicz

\section{Bibliography}

\section{Primary sources}

"Apel KKP w rocznice powstania listopadowego," 26 November 1980, [in:] Dokumenty Krajowej Komisji Porozumiewawczej i Komisji Krajowej NSZZ "Solidarność" (1980-1981), M. Owsiński (ed.), Warszawa 2012.

"Deklaracja," Tygodnik Solidarność 28 (1981), p. 4.

"Deklaracja programowa w sprawie kultury narodowej," Tygodnik Solidarność 30 (1981), p. 9

"Kierunki działania Związku w obecnej sytuacji kraju. Tezy do dyskusji," Tygodnik Solidarność 3 (1981), pp. 1-8 (insert).

Komisja Krajowa NSZZ "Solidarność," Posiedzenie w dniach 23-24 marca, Warszawa 1981.

Kurowski, S., "Inspiracje i źródła programu," Tygodnik Solidarność 4 (1981), p. 5.

Kurowski S., "Wartości ideowe," Tygodnik Solidarność 5 (1981), p. 9.

"Program NSZZ 'Solidarność' uchwalony przez I Krajowy Zjazd Delegatów," Tygodnik Solidarność 29 (1981), p. 1.

"List do Polonii całego świata," [in:] I Krajowy Zjazd Delegatów NSZZ "Solidarność", Gdańsk 1981, p. 44.

Tischner J., Etyka Solidarności, Paris 1982 [1981].

"Uchwała nr 18/81," [in:] I Krajowy Zjazd Delegatów NSZZ "Solidarnośc", Gdańsk 1981, p. 44.

"Uchwała nr 24/81," [in:] I Krajowy Zjazd Delegatów NSZZ "Solidarnośç", Gdańsk 1981, p. 45.

"Uchwała nr 25/81," [in:] I Krajowy Zjazd Delegatów NSZZ "Solidarnośc", Gdańsk 1981, p. 46.

"Uchwała w sprawie mniejszości narodowych," Tygodnik Solidarność 30 (1981), p. 9.

"Uchwała w sprawie walki psychologicznej z narodem," Tygodnik Solidarność 28 (1981), p. 6.

\section{Secondary sources}

Bartyzel J., "Wartość wspólnoty. Filozofia polityczna komunitaryzmu," Myśl Konserwatywna 18 May 2015, http://myslkonserwatywna.pl/prof-bartyzel-wartosc-wspolnoty-filozofia-polityczna-komunitaryzmu (accessed: 12.01.2017).

Bell D.A., "A Communitarian Critique of Authoritarianism: The Case of Singapore," Political Theory 25 (1997), pp. 6-32. 
Bell D.A., "A Communitarian Critique of Authoritarianism," Society 32 (1995), pp. $38-43$.

Brzechczyn K., "Od rewolucji proletariackiej do powstania narodowego. Przegląd konceptualizacji "Solidarności" w naukach społecznych i humanistycznych," Pamięć i Sprawiedliwość 2 (2013) pp. 263-289.

Brzechczyn K. "The Collapse of Real Socialism in Eastern Europe versus the Overthrow of the Spanish Colonial Empire in Latin America: An Attempt at Comparative Analysis," Journal of Interdisciplinary Studies in History and Archaeology 1 (2004), pp. 105-133.

Brzechczyn K., "The Forgotten Legacy of Solidarność and Lost Opportunities to Build a Democratic Capitalist System Following the Fall of Communism in Poland," [in:] Twenty Years after the Collapse of Communism: Expectations, Achievements and Disillusions of 1989, N. Hayoz, L. Jesień, D. Koleva (eds.), Bern 2011, pp. 400-401.

Brzechczyn K., "The Round Table Agreement in Poland as a Case of Class Compromise: An Attempt at a Model," Debatte: Journal of Contemporary Central and Eastern Europe 18 (2010), pp. 185-204.

Chmielewski A., "Komunitaryzm," [in:] Panorama współczesnej filozofii, J. Hołówka, B. Dziobkowski (eds.), Warszawa 2016, pp. 435-453.

Dominiak Ł., Wartość wspólnoty. O filozofii politycznej komunitaryzmu, Toruń 2010.

Etzioni A., "The Responsive Community: A Communitarian Perspective," American Sociological Review 61 (1995), pp. 1-11.

Frysztacki K., "Komunitaryzm: obietnice, nadzieje, ograniczenia," Diametros 8 (2006), pp. 108-119.

Kula M., Narodowe i rewolucyjne, Warszawa 1991.

Kuniński M., "Komunitaryzm, czyli o bliskich związkach filozofii politycznej i socjologii," Diametros 8 (2006), pp. 127-131.

MacIntyre A., After Virtue: A Study in Moral Theory, Notre Dame 2007.

Meller M., "Rola myślenia o historii w ruchu 'Solidarność' w latach 1980-1981," [in:] Solidarność w ruchu, 1980-1981, M. Kula (ed.), Warszawa 2000, pp. 219-266.

Miętek A., "Spór liberałów z komunitarystami," Dialogi Polityczne 7 (2007), pp. 101-111.

Modrzyk A., "Ku wspólnocie posttradycyjnej. Axel Honneth jako krytyk komunitariańskiej filozofii politycznej," Praktyka Teoretyczna 1 (2010), pp. 27-40.

Przybysz P., "Dwa modele człowieka (O sporze liberalizm-komunitaryzm)," Arka 51 (1994), pp. 22-39.

Selznick P., "Thinking about Community: Ten Theses," Society 32 (1995), pp. 33-37. Śpiewak P., "Poszukiwanie wspólnot," [in:] Komunitarianie. Wybór tekstów, P. Śpiewak (ed.), Warszawa 2004, pp. 5-15.

Skórzyński J., Ugoda i rewolucja. Władza i opozycja 1985-1989, Warszawa 1995.

Strzałkowski P., "Polityczne i społeczne uwarunkowania przedsiębiorczości ekonomicznej," [in:] Zmierzch socjalizmu państwowego, W. Morawski (ed.), Warszawa 1994, pp. $342-352$. 
Szahaj A., Jednostka czy wspólnota? Spór liberałów z komunitarystami a sprawa polska, Warszawa 2000.

Walicki A., "Paradoksy Polski Jaruzelskiego," [in:] A. Walicki, Polskie zmagania z wolnościa, Kraków 2000, pp. 11-34. 